\title{
Isolation and primary culture of rat distal pulmonary venous smooth muscle cells
}

\author{
Gongyong Peng ${ }^{1,2}$, Jian Wang ${ }^{1,2}$, Wenju $\mathrm{Lu}^{2}$ and Pixin Ran ${ }^{1}$
}

Primary culture of pulmonary arterial smooth muscle cells is used extensively for in vitro studies of the physiology and pathophysiology of numerous lung diseases, including chronic hypoxic pulmonary hypertension (CHPH). Despite the potentially important functions of pulmonary veins in CHPH, primary culturing of pulmonary venous smooth muscle cells (PVSMCs) has received very little attention to date. No efficient and widely accepted methods have been established. Consequently, related studies have been delayed, which inhibits progress in exploring the mechanisms of CHPH and other lung diseases. In this study, we describe a simple and efficient method of obtaining primary cultures of PVSMCs isolated from rat distal pulmonary veins. By following four steps, isolation of pulmonary veins, enzymatic digestion, concentration of resuspended pellets and incubation, we acquired purified PVSMCs ( $>95 \%$ ). PVSMCs were characterized by morphological activity and by immunoblotting and immunofluorescence staining for $\alpha$-smooth muscle actin. Furthermore, the response of cells to $60 \mathrm{~mm} \mathrm{KCl}$ was tested, confirming the presence of functional L-type voltage-dependent $\mathrm{Ca}^{2+}$ channels that are characteristic of smooth muscle cells. In conclusion, we have established a simple and reliable technique to isolate and culture PVSMCs from rat distal pulmonary veins. These PVSMCs exhibit features consistent with vascular smooth muscle cells, and they could subsequently be used to study pathophysiological mechanisms involving the pulmonary vein.

Hypertension Research (2010) 33, 308-313; doi:10.1038/hr.2009.234; published online 29 January 2010

Keywords: primary cell culture; pulmonary veins; pulmonary venous smooth muscle cells; rat

\section{INTRODUCTION}

Chronic hypoxia causes remodeling and alters contractile responses in both pulmonary arteries and pulmonary veins. ${ }^{1-5}$ Primary cultures of pulmonary arterial smooth muscle cells (PASMCs) isolated from pulmonary arteries have been widely used to study the molecular mechanisms by which pulmonary arteries respond to hypoxia. These hypoxic responses greatly contribute to the pathogenesis and development of chronic hypoxic pulmonary hypertension (CHPH) ${ }^{6-8}$ Although pulmonary veins also contain smooth muscle that is likely to be important in $\mathrm{CHPH}$, the absence of reliable methods to culture pulmonary venous smooth muscle cells (PVSMCs) has greatly delayed the related research. Thus, there is a need for an easy, reliable and widely accepted method to obtain these cells.

The purpose of this study was to develop a simple and efficient technique to isolate pulmonary veins, obtain primary cultures of PVSMCs and further characterize the phenotype and physiological functions of these cells. A method for primary cell culture of PVSMCs would be of great value for in vitro experiments to explore the mechanisms of $\mathrm{CHPH}$ and other pulmonary vein dysfunctions.

\section{METHODS}

Rats

Male Wistar rats (body weight $200-400 \mathrm{~g}$ ) were used in all experiments. The rats were housed in community cages with 12:12-h light-dark cycles and maintained on a standard laboratory rat diet with access to water. All animal care and experiments were approved and carried out in accordance with the Animal Care and Use Committee of the Johns Hopkins Medical Institutions and in accordance with the principles and guidelines of the National Institutes of Health.

\section{Drugs and materials}

Unless otherwise specified, all reagents were obtained from Sigma Chemical. HUVEC and culture media, including smooth muscle cell growth medium and endothelial cell growth medium, were obtained from Clonetics (Walkersville, MD, USA); ENVISION kit was from Dako (Glostrup, Denmark); fetal bovine serum, PBS and antibiotic-antimycotic were from GIBCO (Carlsbad, CA, USA); rabbit anti-rat antibody for von Willebrand Factor was from Abcam (Cambridge, MA, USA); Cy3-conjugated secondary antibody goat anti-mouse IgG antibody and donkey anti-rabbit IgG antibody were from Jackson ImmunoResearch (West Grove, PA, USA); the bicinchoninic acid protein assay was from Pierce (Rockford, IL, USA); protein molecular weight markers and polyvinylidene difluoride membranes were from Bio-Rad (Hercules, CA, USA);

${ }^{1}$ Guangzhou Institute of Respiratory Disease, State Key Laboratory of Respiratory Diseases, Guangzhou Medical University, Guangzhou, PR China and ${ }^{2}$ Division of Pulmonary and Critical Care Medicine, The Johns Hopkins University School of Medicine, Baltimore, MD, USA

Correspondence: Dr P Ran or J Wang, Guangzhou Institute of Respiratory Diseases, State Key Laboratory of Respiratory Diseases, The First Affiliated Hospital, Guangzhou Medical University, 151 Yanjiang Road, Guangzhou, Guangdong, 510120, PR China.

E-mail: pxran@vip.163.com or Dr J Wang, Division of Pulmonary and Critical Care Medicine, The Johns Hopkins University School of Medicine, Baltimore, MD 21224, USA. E-mail: jwang31@jhmi.edu

Received 20 May 2009; revised 3 December 2009; accepted 9 December 2009; published online 29 January 2010 
the enhanced chemiluminescence system was from GE Healthcare (Piscataway, NJ, USA); and Fura-2 AM was from Invitrogen (Carlsbad, CA, USA).

\section{Histology and immunohistochemistry}

Rats were deeply anesthetized with pentobarbital sodium $\left(65 \mathrm{mg} \mathrm{kg}^{-1} \mathrm{ip}\right)$, and anesthesia was confirmed by the lack of a withdrawal reflex from a toe pinch. Lungs were removed intact and fixed overnight after infusion of $5 \mathrm{ml}$ of $10 \%$ neutral-buffered formalin through the trachea. After paraffin embedding, sections $(3 \mu \mathrm{m})$ of the right and left low lobes were examined with hematoxylin and eosin and immunohistochemical staining.

Immunostaining for $\alpha$-smooth muscle actin was performed using the ENVISION kit method as described earlier. ${ }^{9-11}$ Briefly, the slides were deparaffinized and rehydrated in graded concentrations of ethanol diluted in distilled water. Endogenous peroxidase activity was blocked with $3 \%$ hydrogen peroxide for $10 \mathrm{~min}$ at room temperature (RT), followed by a brief rinse in distilled water and a wash in PBS. The slides were then placed in $0.01 \mathrm{M}$ citrate buffer ( $\mathrm{pH}$ 6.0) and heated at $121{ }^{\circ} \mathrm{C}$ for $10 \mathrm{~min}$ in an autoclave oven. Nonspecific background staining was inhibited by incubation in PBS with $1 \%$ bovine serum albumin for $30 \mathrm{~min}$ at RT. Slides were incubated in a solution containing the primary antibody against $\alpha$-smooth muscle actin $(1: 100)$ for $40 \mathrm{~min}$ at $37^{\circ} \mathrm{C}$, followed by a wash in PBS. Thereafter, immunoperoxidase staining was performed with the EnVision antibody complex method using an ENVISION kit. Finally, the localization of $\alpha$-smooth muscle actin was visualized with 3,3'-diaminobenzidine tetrahydrochloride.

\section{Cell isolation}

Under sterile conditions, anaesthetized rats were placed in the supine position and their chests were opened. The heart and lungs were removed en bloc and transferred to a Petri dish with cold $\left(4^{\circ} \mathrm{C}\right)$ physiological salt solution (PSS) that contained (in mM) $130 \mathrm{NaCl}, 5 \mathrm{KCl}, 1.2 \mathrm{MgCl}_{2}, 10$ HEPES and 10 glucose. After being rinsed twice with cold PSS, the heart and lungs were placed in the veinsup position and fixed in an isolation dish with syringe needles. Under a stereomicroscope, we first identified the extrapulmonary veins connected with the left cardiac atrium. The right and left branches of the intrapulmonary veins ( $>4$ th generation) that followed the extrapulmonary veins were carefully dissected from the lungs within $30 \mathrm{~min}$ of the time when the heart and lungs were removed from the thoracic cavity. Adipose and connective tissue and any adventitia were carefully removed in cold $\mathrm{Ca}^{2+}$-reduced PSS $\left(20 \mu \mathrm{M} \mathrm{CaCl}_{2}\right)$ with microdissection forceps and scissors. The veins were cut lengthwise to expose the lumen. The endothelium was denuded by gently rubbing the luminal surface with a cotton swab. The veins were allowed to recover for $30 \mathrm{~min}$ in cold $\left(4{ }^{\circ} \mathrm{C}\right)$ PSS. This step was followed by a 20 -min incubation in $\mathrm{Ca}^{2+}$-reduced PSS at RT. The tissue was then digested at $37^{\circ} \mathrm{C}$ for $22 \mathrm{~min}$ in $\mathrm{Ca}^{2+}$-reduced PSS containing collagenase (type I, $\left.1,750 \mathrm{U} \mathrm{ml}^{-1}\right)$, papain $\left(9.5 \mathrm{U} \mathrm{ml}^{-1}\right)$, bovine serum albumin $\left(2 \mathrm{mg} \mathrm{m}^{-1}\right)$ and dithiothreitol $(1 \mathrm{mM})$. The digested tissue was kept in a $15-\mathrm{ml}$ plastic conical tube by carefully decanting the upper collagenase enzymatic solution. Thereafter, $5 \mathrm{ml}$ of PSS was added into the plastic conical tube. The cells were separated from the tissue by gently triturating the solution about 20 times with a wide-bore transfer pipette set to $1 \mathrm{ml}$. The cells were then centrifuged for $10 \mathrm{~min}$ at $300 \mathrm{~g}$ at RT. The supernatant was carefully discarded. After resuspension of the cell pellet, cells were plated onto culture plates and incubated in smooth muscle growth medium containing $5 \%$ fetal bovine serum in a humidified atmosphere of $5 \% \mathrm{CO}_{2}, 95 \%$ air at $37^{\circ} \mathrm{C}$. The media were removed and replaced every $2-3$ days. Cell growth and cell morphology were examined daily under an inverted light microscope.

\section{Cell identification}

Immunofluorescence. Smooth muscle cells were identified by the presence of $\alpha$-smooth muscle actin using a monoclonal antibody. The cells not treated with the primary antibody specific for $\alpha$-smooth muscle actin were used as negative control. The smooth muscle cells were also identified by the absence of von Willebrand Factor. HUVECs were used as a positive control.

The cells were seeded and grown on sterile coverslips in a humidified atmosphere of $5 \% \mathrm{CO}_{2}, 95 \%$ air at $37^{\circ} \mathrm{C}$ for $4-5$ days. They were then rinsed twice with PBS and fixed for $15 \mathrm{~min}$ with $2 \mathrm{ml}$ of $4 \%$ paraformaldehyde in PBS at RT, after which the cells were rinsed three times with PBS and treated for 15 min with $2 \mathrm{ml}$ of PBS containing $0.25 \%$ Triton X-100 at RT. The permeabilization buffer was aspirated, and cells were rinsed three times with $2 \mathrm{ml}$ of PBS for 5 min each. Cells were incubated at RT for 30 min in PBS with $1 \%$ bovine serum albumin and then for $60 \mathrm{~min}$ at RT with a monoclonal mouse anti-rat antibody to $\alpha$-smooth muscle actin (1:200) or with a rabbit anti-rat antibody to von Willebrand Factor (1:200). To visualize the proteins, cells were treated for $2 \mathrm{~h}$ at $\mathrm{RT}$ in the dark with a Cy3-conjugated secondary goat antimouse or donkey anti-rabbit IgG (Fab specific) antibody (1:100), which produced red fluorescence. Cells were rinsed and incubated with YO-PRO-1 solution at $3.5 \mu \mathrm{ml}^{-1}$ for $5 \mathrm{~min}$ at RT away from light. The coverslips were mounted with a drop of mounting medium.

\section{Western blot}

We further characterized our primary cultured cells by western blot analysis using a smooth muscle cell-specific antibody, which detects the presence of $\alpha$-smooth muscle actin. HUVECs and primary cultures of rat PASMCs, isolated and cultured as described earlier, ${ }^{6,7,12}$ were used as a control.

Cell samples were homogenized by sonication in Laemmlie sample buffer containing $62.5 \mathrm{~mm}$ Tris- $\mathrm{HCl}$ (pH 6.8), 2\% SDS, 10\% glycerol, $5 \%$ protease inhibitor cocktail, $1 \mathrm{~mm}$ EDTA and $200 \mu \mathrm{M}$ 4-(2-aminoethyl) benzenesulfonyl fluoride hydrochloride. The total protein concentration in the homogenates was determined by the bicinchoninic acid protein assay using bovine serum albumin as a standard. Homogenates were denatured by adding dithiothreitol to reach a concentration of $150 \mathrm{~mm}$ and heating at $95^{\circ} \mathrm{C}$ for $5 \mathrm{~min}$. Homogenized proteins were resolved by $10 \%$ SDS-PAGE calibrated with prestained protein molecular weight markers. Separated proteins were transferred to polyvinylidene difluoride membranes (pore size $0.45 \mu \mathrm{M}$ ). Membranes were blocked with $5 \%$ nonfat dry milk in Tris-buffered saline containing $0.2 \%$ Tween 20 , and they were incubated with mouse monoclonal anti-rat primary antibody (1:1000) specific for $\alpha$-smooth muscle actin. The membranes were then washed for $15 \mathrm{~min}$ three times and incubated with horseradish peroxidase-conjugated goat anti-mouse IgG for $1 \mathrm{~h}$. Enhanced chemiluminescence was used to detect bound antibodies.

\section{Response to high $\mathrm{K}^{+}$solution}

To confirm the presence of functional voltage-dependent $\mathrm{Ca}^{2+}$ channels (VDCCs) in smooth muscle cells, we determined the effect of $60 \mathrm{~mm} \mathrm{KCl}$ on $\left[\mathrm{Ca}^{2+}\right]_{i}$. Primary cultures of rat PASMCs were used as a positive control.

As described earlier, ${ }^{6,12}$ after incubation with $5 \mu \mathrm{M}$ fura-2 AM for $60 \mathrm{~min}$ at $37^{\circ} \mathrm{C}$ under an atmosphere of $5 \% \mathrm{CO}_{2}, 95 \%$ air, coverslips with cells were mounted in a closed polycarbonate chamber clamped in a heated aluminum platform (PH-2; Warner Instrument, Hamden, CT, USA) on the stage of a Nikon TSE 100 Ellipse inverted microscope (Melville, NY, USA). The chamber was perfused at $0.5-1 \mathrm{ml} \mathrm{min}^{-1}$ with Krebs-Ringer Bicarbonate solution (KRBS), containing (in mM) $118 \mathrm{NaCl}, 4.7 \mathrm{KCl}, 0.57 \mathrm{MgSO}_{4}, 1.18 \mathrm{KH}_{2} \mathrm{PO}_{4}$, $25 \mathrm{NaHCO}_{3}, 2.5 \mathrm{CaCl}_{2}$ and 10 glucose. The KRBS was equilibrated with $16 \%$ $\mathrm{O}_{2}, 5 \% \mathrm{CO}_{2}$ at $38^{\circ} \mathrm{C}$ in heated reservoirs and led by means of a stainless steel tubing manifold to an inline heat exchanger (SF-28, Warner Instrument), which rewarmed the perfusate just before it entered the cell chamber. The temperature of the heat exchanger and chamber platform was controlled by a dual-channel heater controller (TC-344B, Warner Instrument). After perfusion for $10 \mathrm{~min}$ to remove extracellular dye, we measured fura-2 fluorescence emitted at $510 \mathrm{~nm}$ after excitation at 340 and $380 \mathrm{~nm}$ (F340, F380) at $30 \mathrm{~s}$ intervals in 20-30 cells using a xenon arc lamp, interference filters, electronic shutter, $\times 20$ fluorescence objective and cooled charge-coupled device imaging camera. Protocols were executed, and data were collected online with InCyte software (Intracellular Imaging, Cincinnati, OH, USA). Fura-2 fluorescence ratios $(R=\mathrm{F} 340 / \mathrm{F} 380)$ allowed estimation of $\left[\mathrm{Ca}^{2+}\right]_{i}$ from $R$ measured in calibration solutions with $\left[\mathrm{Ca}^{2+}\right]$ between 0 and $1350 \mathrm{~nm}$ (Invitrogen). After perfusion with KRBS for $5 \mathrm{~min}$, cells were perfused at $37^{\circ} \mathrm{C}$ with high $\mathrm{K}^{+} \mathrm{KRBS}$ containing (in mM) $60 \mathrm{NaCl}, 60 \mathrm{KCl}, 0.57 \mathrm{MgSO}_{4}, 1.18 \mathrm{KH}_{2} \mathrm{PO}_{4}, 25 \mathrm{NaHCO}_{3}$, $2.5 \mathrm{CaCl}_{2}$ and 10 glucose. After an additional $10 \mathrm{~min}$, the cells were perfused with KRBS for $10 \mathrm{~min}$. To block the $\left[\mathrm{Ca}^{2+}\right]_{i}$ response to $\mathrm{KCl}$, we perfused cells for $5 \mathrm{~min}$ with KRBS containing $5 \mu \mathrm{M}$ nifedipine and then for $10 \mathrm{~min}$ with high 
$\mathrm{K}^{+}$KRBS containing $5 \mu \mathrm{M}$ nifedipine. Finally, we perfused the cells for $10 \mathrm{~min}$ with KRBS.

\section{Statistical analysis}

Data are expressed as means \pm s.e.; $n$ is the number of experiments, which equals the number of animals providing veins or cells. When fura-2 fluorescence was measured, the number of cells in each experiment was 20-30, as indicated in Results section and the legends for Figures 6 and 7. Statistical analyses were performed using Student's $t$-test. Differences were considered significant when $P<0.05$.

\section{RESULTS}

\section{Histology and immunohistochemistry}

Histological examination of hemotoxylin- and eosin-stained rat lung tissue sections showed that intrapulmonary veins were thinner than concomitant intrapulmonary arteries (Figure 1a), and the tunica media of intrapulmonary veins consisted mostly of circularly arranged smooth muscle (Figure 1b).

Immunohistochemical staining showed that intrapulmonary veins expressed $\alpha$-smooth muscle actin, although the expression was weaker than that of intrapulmonary arteries (Figure 1c). Figure 1d, a higher power view of the intrapulmonary veins in Figure 1c, further indicated that the tunica media of intrapulmonary veins consists mainly of smooth muscle cells and that the amount is similar to that of concomitant bronchi.

\section{Cell morphology}

As shown in Figure 2, the pulmonary veins used in this study were isolated from $>4$ th generation intrapulmonary venous branches. Our primary cultured cells were identified on the basis of their patterns of growth, morphology, immunohistological staining, western blotting and functional characteristics.

Observed with a phase-contrast microscope, the cells started to divide and extend within 3 days. The cells were phase bright and assumed a spindle-shaped appearance with cytoplasmic projections extending from a larger central area that contained the nucleus (Figure 3a). When the cells grew to higher density, they clustered
(Figure 3b) and formed longitudinal bands of parallel cells (Figure 3c). This growth pattern was observed in all primary cultures of rat distal PVSMCs. As soon as the cells became confluent, they grew in a 'hilland-valley'-like pattern, which is characteristic of smooth muscle cells (Figure 3d). The PVSMCs grew to confluence (80\%) in 7-8 days.

\section{Immunofluorescence}

The cultured cells stained positively for $\alpha$-smooth muscle actin antibody. The staining revealed typical straight, noninterrupted, cable-like fibers running parallel to each other along the long axis of the cells (Figure 4a). When the cells became confluent, the cytoplasm of the PVSMCs filled densely with arranged fibers that stained strongly for $\alpha$ smooth muscle actin (Figure 4b). The immunocytochemical fluorescence of $\alpha$-actin is not observed in control PVSMCs, which did not receive the primary monoclonal antibody raised against $\alpha$-smooth muscle actin, but were otherwise treated similarly (Figure 4c). The smooth muscle cells were also identified by the absence of von Willebrand Factor. The staining of PVSMCs for von Willebrand Factor was similar to background levels (Figure 4d). However, the von Willebrand Factor was strongly positive in HUVECs, which were used as a positive control (Figure 4e). As shown in Figure 4f, immunofluorescence for von Willebrand Factor is not shown in HUVECs that did not receive the primary antibody raised against von Willebrand Factor. These data show that our cultured cells were, in fact, smooth muscle cells.

\section{Western blot}

Western blotting showed that our cultured cells expressed $\alpha$-smooth muscle actin (MW: $42 \mathrm{kDa}$ ) (Figure 5), showing similar $\alpha$-actin expression to that of earlier established PASMCs in culture. HUVECs did not express $\alpha$-smooth muscle actin.

\section{Response to high $\mathrm{K}^{+}$solution}

To confirm the presence of functional VDCCs, which is characteristic of smooth muscle cells, we determined the effect of $60 \mathrm{mM} \mathrm{KCl}$ on $\left[\mathrm{Ca}^{2+}\right]_{i}$ in our cultured cells from rat distal pulmonary veins. The cells,
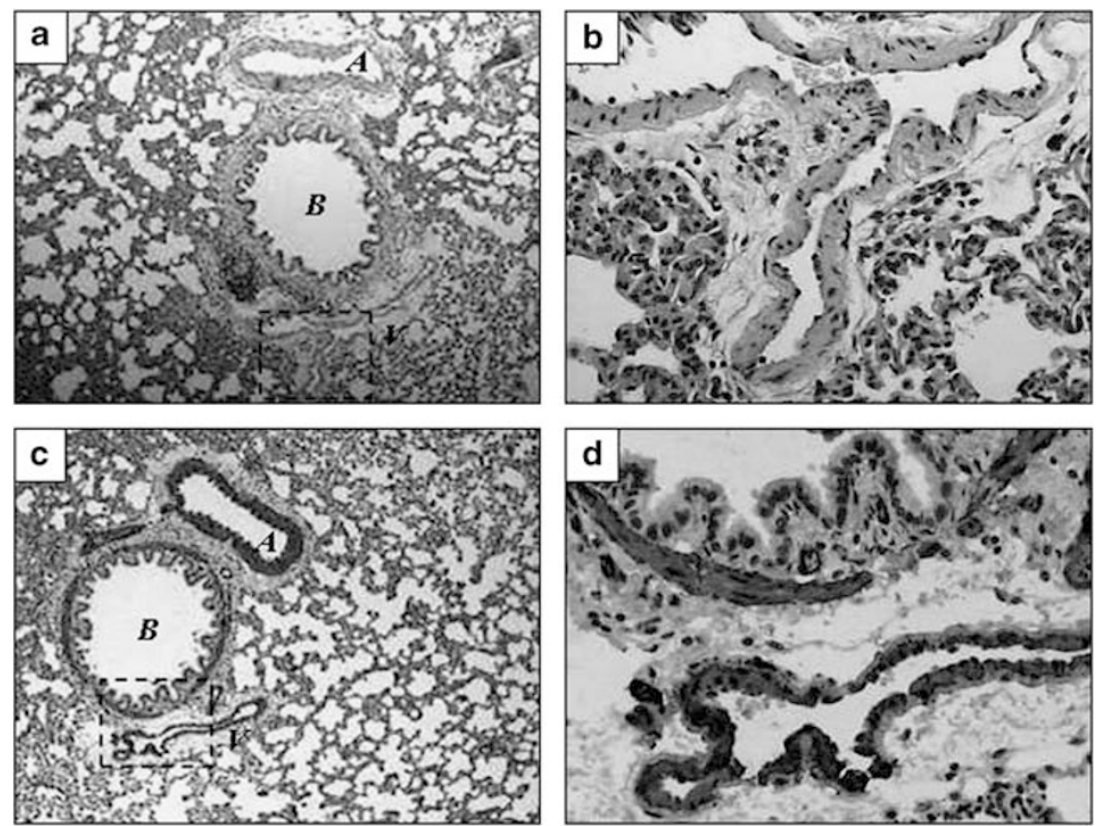

Figure 1 Hematoxylin and eosin staining of lung tissue sections (a, b, enlarged from inset in a) and immunostaining for $\alpha$-smooth muscle actin in lung tissue sections (c, d, enlarged from inset in c). Bronchi, arteries and veins are labeled as B, A and V, respectively. 

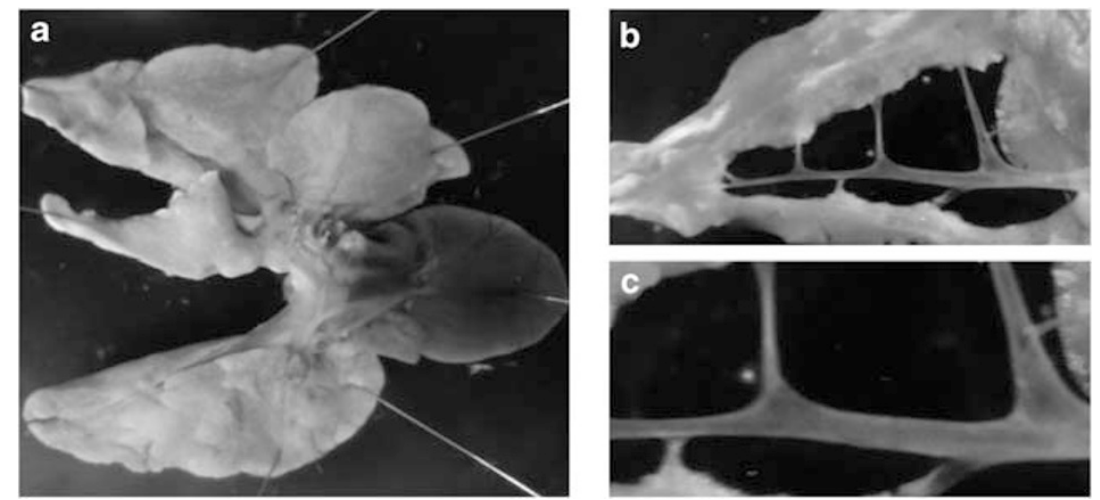

Figure 2 (a) The heart and lungs were placed in the veins-up position and fixed in an isolation dish with syringe needles. (b) Intrapulmonary venous branches isolated from the right lung. (c) The zoomed image showing the branches used for the experiment.
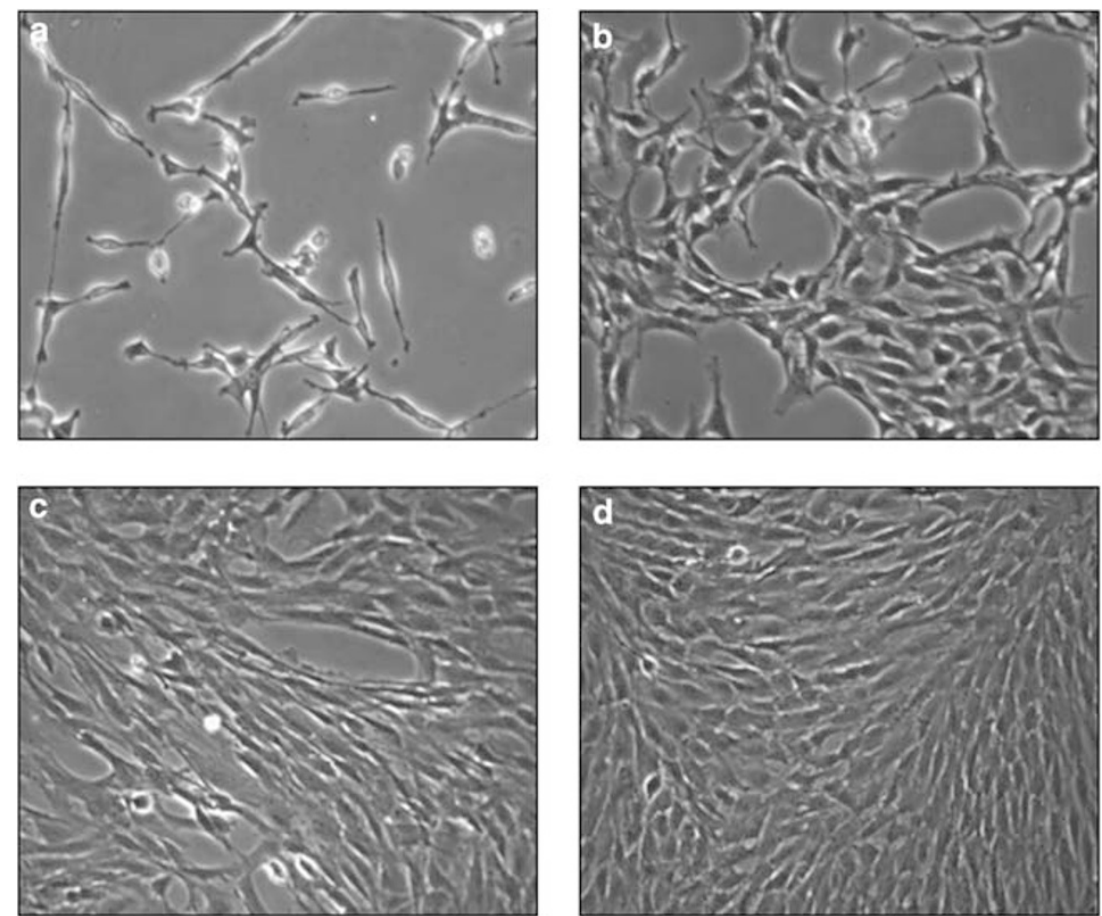

Figure 3 Phase-contrast microscopy of rat distal pulmonary venous smooth muscle cells (PVSMCs) (a) cultured for 2 days, (b) cultured for 4 days, (c) cultured for 6 days and (d) cultured for 8 days.

similar to PASMCs, showed a clear increase in $\left[\mathrm{Ca}^{2+}\right]_{i}$ in response to $60 \mathrm{mM} \mathrm{KCl} \mathrm{(Figure} \mathrm{6a).} \mathrm{Peak} \Delta\left[\mathrm{Ca}^{2+}\right]_{i}$ averaged $166 \pm 28 \mathrm{nM}$ in PVSMCs $(n=5 ; P=0.91$ vs PASMCs), compared with $161 \pm 38 \mathrm{~nm}$ $(n=4)$ in PASMCs (Figure 6b). As shown in Figure $7 \mathrm{a}$, the L-type VDCC antagonist nifedipine administered at a $5-\mu \mathrm{M}$ concentration completely blocked the $\left[\mathrm{Ca}^{2+}\right]_{i}$ response to $\mathrm{KCl}$ in PVSMCs. Peak $\Delta\left[\mathrm{Ca}^{2+}\right]_{i}$ averaged $177 \pm 29 \mathrm{nM}$ in control PVSMCs $(n=6 ; P<0.01$ vs nifedipine) vs $8 \pm 2 \mathrm{nM}(n=6)$ in PVSMCs perfused with high $\mathrm{K}^{+}$ KRBS containing $5 \mu \mathrm{M}$ nifedipine (Figure $7 \mathrm{~b}$ ).

\section{DISCUSSION}

In this study, we describe an easy and reliable method to acquire primary cultures of PVSMCs from rat distal pulmonary veins for in vitro studies of pulmonary vessel-related diseases. The distal pulmonary veins were isolated from $>4$ th generation intrapulmonary venous branches. The distal veins consisted mainly of smooth muscle cells, showing characteristic histological and immunological features consistent with earlier observations. ${ }^{13,14}$ The amount of smooth muscle was similar to that of concomitant intrapulmonary bronchi.

In our subsequent experiments, the rat distal PVSMCs that we obtained exhibited characteristic morphological features, immunoreactivity to $\alpha$-smooth muscle actin antibody and physiological functions that are consistent with observations from other investigators. ${ }^{15-17}$ PVSMCs started to divide within 3 days, and the culture reached confluence in approximately 1 week. As soon as the cells became confluent, the primary culture of PVSMCs, similar to other vascular smooth muscle cells described by other investigators, ${ }^{15,16,18}$ grew in a 'hill-and-valley'-like pattern, which is characteristic of smooth muscle cell growth. 

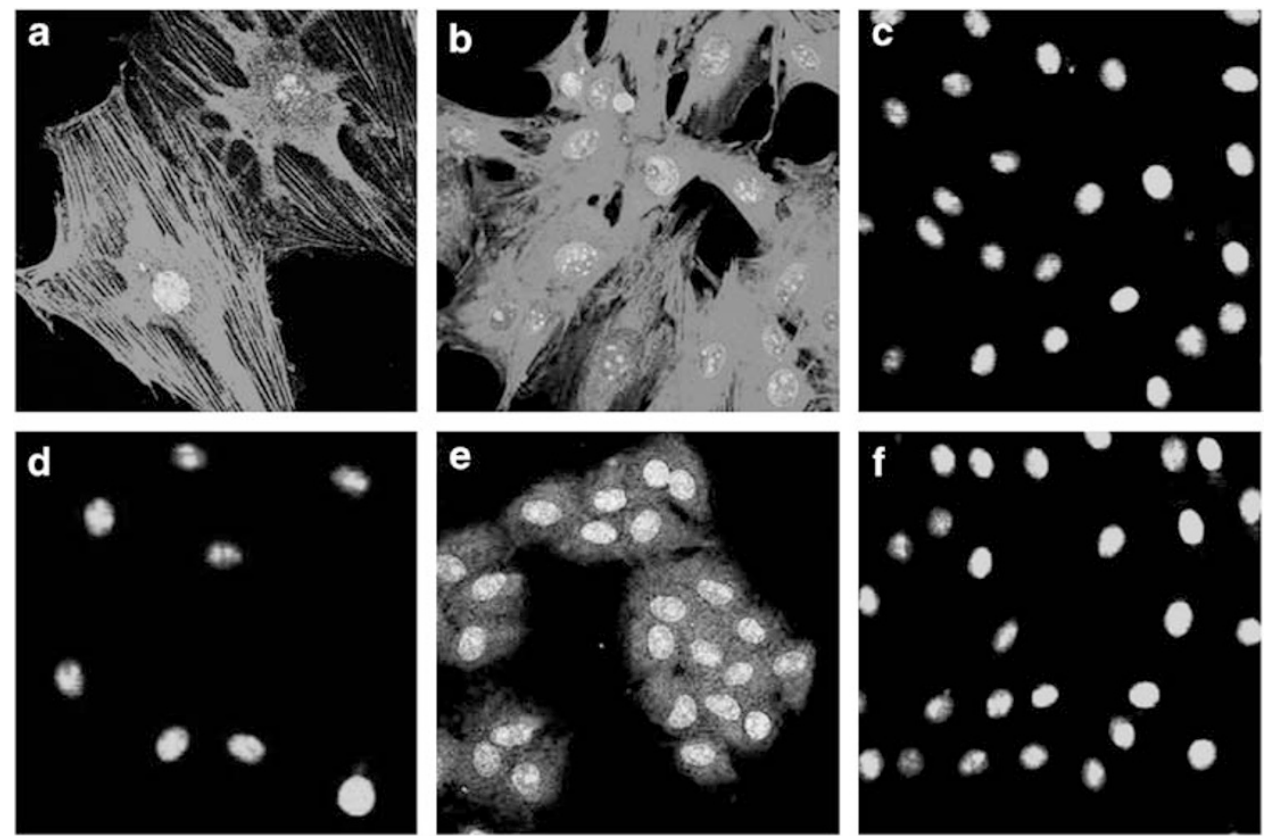

Figure 4 (a, b) Fluorescence immunocytochemical identification of $\alpha$-actin (shown in red) in PVSMCs (a) PVSMCs showed typical straight, noninterrupted, cable-like fibers running parallel to each other along the long axis of the cells. (b) When the cells became confluent, PVSMCs were filled densely with arranged fibers that stained strongly for $\alpha$-actin. The nuclear marker YO-PRO-1 is shown in green. (c) Fluorescence immunocytochemical identification of $\alpha$-actin is not shown in control PVSMCs, which did not receive primary monoclonal antibody raised against $\alpha$-smooth muscle actin, but were otherwise treated similarly. (d) The staining of PVSMCs for von Willebrand Factor was similar to the background. (e) HUVECs strongly expressed von Willebrand Factor (shown in red). (f) Immunofluorescence for von Willebrand Factor is not shown in control HUVECs that did not receive the primary antibody raised against von Willebrand Factor. A full color version of this figure is available at the Hypertension Research journal online.

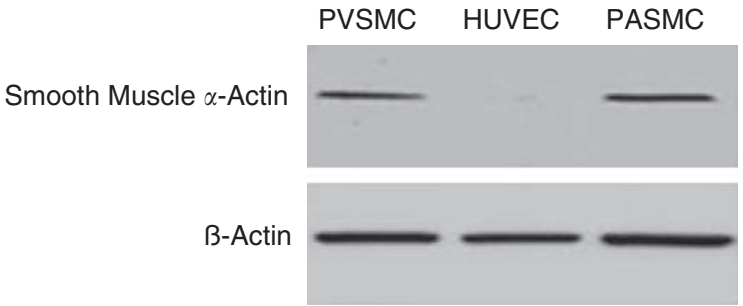

Figure 5 Western blot for $\alpha$-smooth muscle actin. PVSMCs expressed $\alpha$-smooth muscle actin. PASMC $\alpha$-actin expression was similar to that of PVSMCs. HUVECs did not express $\alpha$-smooth muscle actin.

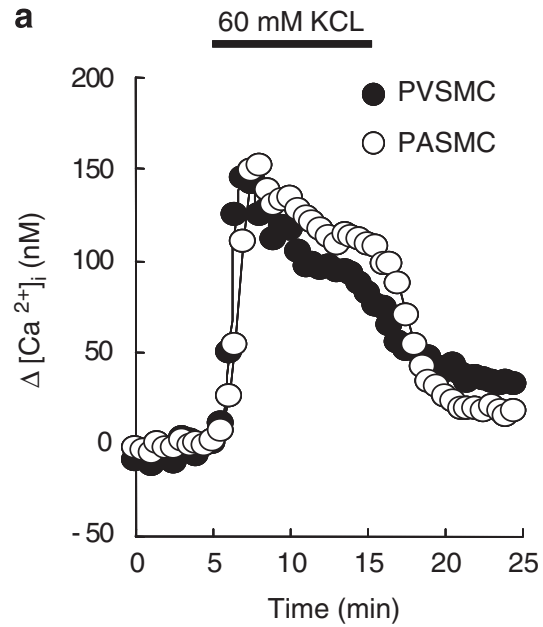

Both immunoblotting and immunostaining verified that the established primary PVSMC cultures consisted of vascular smooth muscle cells. Using immunoblotting, we found that PVSMCs, similar to PASMCs, expressed $\alpha$-smooth muscle actin, whereas HUVECs did not express the protein. PVSMCs showed uniform immunostaining for $\alpha$-smooth muscle actin and lack of von Willebrand Factor.

Many investigators have reported that vascular smooth muscle cells can respond to high $\mathrm{K}^{+}$solution $^{5,12,19}$ and that an L-type VDCC antagonist can inhibit the response. ${ }^{16,20-22}$ In this study, we compared the $\mathrm{KCl}$-induced response by measuring peak $\Delta\left[\mathrm{Ca}^{2+}\right]_{i}$. We observed similar results in both PVSMCs and PASMCs. The L-type VDCC

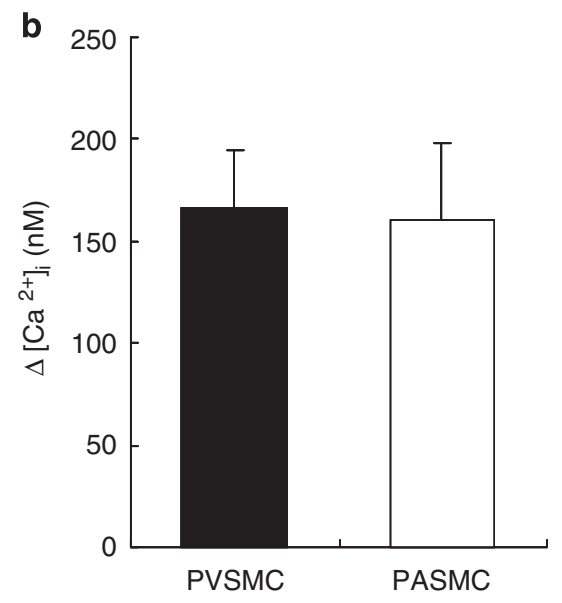

Figure 6 (a) Time course of $\left[\mathrm{Ca}^{2+}\right]_{i}$ before and after perfusion of $60 \mathrm{~mm} \mathrm{KCl}$ in PVSMCs ( $n=5$ experiments in 130 cells) and PASMCs ( $n=4$ experiments in 98 cells). (b) Average peak $\left[\mathrm{Ca}^{2+}\right]_{i}$ obtained from cells shown in (a). 

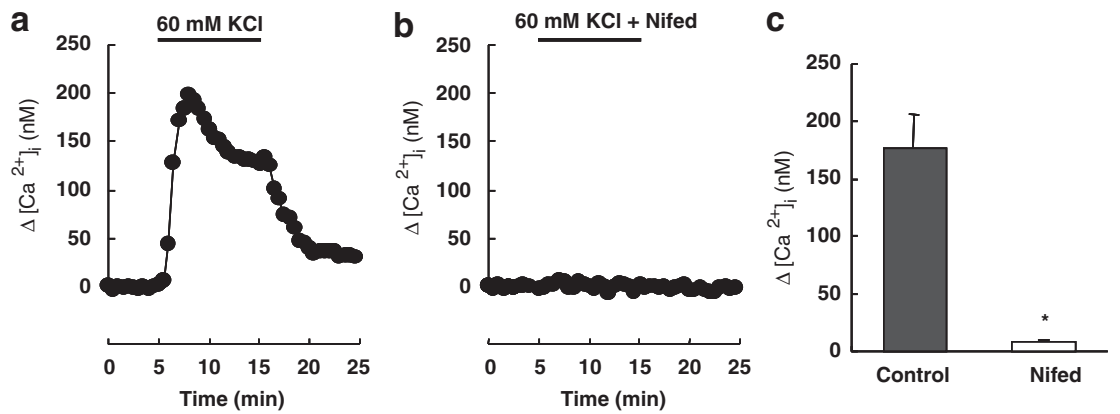

Figure 7 (a) $\mathrm{Ca}^{2+}$ responses of PVSMCs to $60 \mathrm{~mm} \mathrm{KCl}$ ( $n=6$ experiments in 148 cells). (b) The effect of $5 \mu \mathrm{m}$ nifedipine on Ca ${ }^{2+}$ responses of PVSMCs to $60 \mathrm{~mm} \mathrm{KCl}$ ( $n=6$ experiments in 141 cells). (c) Average peak $\left[\mathrm{Ca}^{2+}\right]_{i}$ obtained from cells shown in (a, b)

antagonist nifedipine completely blocked the $\left[\mathrm{Ca}^{2+}\right]_{i}$ response to $\mathrm{KCl}$, indicating that functional VDCCs were also present in PVSMCs. These data clearly showed that the cells that we acquired and cultured were indeed vascular smooth muscle cells in good condition.

In summary, we have established a simple and efficient method to obtain PVSMCs from rat distal pulmonary veins. PVSMCs show the morphological characteristics of vascular smooth muscle cells, express $\alpha$-smooth muscle actin and possess the L-type VDCC consistent with their vascular smooth muscle cell origin. PVSMCs could subsequently be used to further explore the pathophysiological mechanisms of diseases of pulmonary veins, such as $\mathrm{CHPH}$ and pulmonary edema.

\section{ACKNOWLEDGEMENTS}

This work was supported by the NIH Independent Scientist Award (HL079981, J Wang), a research grant from the American Lung Association of Maryland (J Wang), the National Natural Science Foundation of China (30770953), the Guangzhou Department of Education, China (J Wang) and the Chinese Central Government key research projects of the 973 grants (2009CB522107). G Peng was supported by the China Scholarship Council (20073021); J Wang is a Zhujiang Scholar of Guangdong province, China.

1 Dingemans KP, Wagenvoort CA. Pulmonary arteries and veins in experimental hypoxia. An ultrastructural study. Am J Pathol 1978; 93: 353-368.

2 Hasebe N, Onodera S, Yamashita H, Kawamura Y, Haneda T, Tobise K. Site of hypoxic pulmonary vasoconstriction in pulsatile perfused canine lung lobes. Jpn Circ J 1992; 56: 837-846.

3 Schindler MB, Hislop AA, Haworth SG. Postnatal changes in pulmonary vein responses to endothelin-1 in the normal and chronically hypoxic lung. Am J Physiol Lung Cell Mol Physiol 2007; 292: L1273-L1279.

4 Uzun O, Tuncay Demiryurek A. Involvement of tyrosine kinase pathway in acute hypoxic vasoconstriction in sheep isolated pulmonary vein. Vascul Pharmacol 2003; 40 175-181.

5 Zhao Y, Packer CS, Rhoades RA. Pulmonary vein contracts in response to hypoxia. Am J Physiol 1993; 265: L87-L92.

6 Wang J, Shimoda LA, Weigand L, Wang W, Sun D, Sylvester JT. Acute hypoxia increases intracellular $[\mathrm{Ca} 2+]$ in pulmonary arterial smooth muscle by enhancing capacitative Ca2+ entry. Am J Physiol Lung Cell Mol Physiol 2005; 288: L1059-L1069.

7 Wang J, Weigand L, Lu W, Sylvester JT, Semenza GL, Shimoda LA. Hypoxia inducible factor 1 mediates hypoxia-induced TRPC expression and elevated intracellular Ca2+ in pulmonary arterial smooth muscle cells. Circ Res 2006; 98: 1528-1537.

8 Wang J, Weigand L, Wang W, Sylvester JT, Shimoda LA. Chronic hypoxia inhibits Kv channel gene expression in rat distal pulmonary artery. Am J Physiol Lung Cell Mol Physiol 2005; 288: L1049-L1058.

9 Kämmerer U, Kapp M, Gassel AM, Richter T, Tank C, Dietl J, Ruck P. A new rapid immunohistochemical staining technique using the EnVision antibody complex. Histochem Cytochem 2001; 49: 623-630.

10 Nozoe T, Korenaga D, Kabashima A, Ohga T, Saeki H, Sugimachi K. Significance of cyclin B1 expression as an independent prognostic indicator of patients with squamous cell carcinoma of the esophagus. Clin Cancer Res 2002; 8: 817-822.

11 Linderoth J, Jerkeman M, Cavallin-Ståhl E, Kvaløy S, Torlakovic E. Immunohistochemical expression of CD23 and CD40 may identify prognostically favorable subgroups of diffuse large B-cell lymphoma: a Nordic Lymphoma Group Study. Clin Cancer Res 2003; 9: 722-728.

12 Wang J, Shimoda LA, Sylvester JT. Capacitative calcium entry and TRPC channel proteins are expressed in rat distal pulmonary arterial smooth muscle. Am J Physiol Lung Cell Mol Physiol 2004; 286: L848-L858.

13 Takahashi H, Soma S, Muramatsu M, Oka M, Fukuchi Y. Upregulation of ET-1 and its receptors and remodeling in small pulmonary veins under hypoxic conditions. Am J Physiol Lung Cell Mol Physiol 2001; 280: L1104-L1114.

14 Hall SM, Hislop AA, Haworth SG. Origin, differentiation, and maturation of human pulmonary veins. Am J Respir Cell Mol Biol 2002; 26: 333-340.

15 Heimli H, Kähler H, Endresen MJ, Henriksen T, Lyberg T. A new method for isolation of smooth muscle cells from human umbilical cord arteries. Scand J Clin Lab Invest 1997; 57: 21-29.

16 Seidel MF, Simard JM, Hunter SF, Campbell GA. Isolation of arteriolar microvessels and culture of smooth muscle cells from cerebral cortex of guinea pig. Cell Tissue Res 1991; 265: 579-587.

17 Teng B, Ansari HR, Oldenburg PJ, Schnermann J, Mustafa SJ. solation and characterization of coronary endothelial and smooth muscle cells from A1 adenosine receptorknockout mice. Am J Physiol Heart Circ Physiol 2006; 290: H1713-H1720.

18 Hall KL, Harding JW, Hosick HL. Isolation and characterization of clonal vascular smooth muscle cell lines from spontaneously hypertensive and normotensive rat aortas. In Vitro Cell Dev Biol 1991; 27A: 791-798.

19 Heaps CL, Parker JL, Sturek M, Bowles DK. Altered calcium sensitivity contributes to enhanced contractility of collateral-dependent coronary arteries. J App/ Physiol 2004; 97: 310-316.

20 Liu QY, Li B, Gang JM, Karpinski E, Pang PK. Tetrandrine, a Ca++ antagonist: effects and mechanisms of action in vascular smooth muscle cells. J Pharmacol Exp Ther 1995; 273: 32-39.

21 Kalthof B, Bechem M, Pott L, Schramm M. Monitoring of $\mathrm{Ca}(2+)$-transients in electrically stimulated $\mathrm{A} 7 \mathrm{r} 5$ vascular smooth muscle cells fills the experimental gap between KCL-induced depolarization and patch-clamp studies. J Pharmacol Toxicol Methods 1993; 30: 143-147.

22 Bodin P, Richard S, Travo C, Berta P, Stoclet JC, Papin S, Travo P. Responses of subcultured rat aortic smooth muscle myocytes to vasoactive agents and $\mathrm{KCl}$-induced depolarization. Am J Physiol 1991; 260: C151-C158. 